\title{
To Be Good or To Be Better: Asset Managers' Attitudes Towards Herding
}

\author{
Torben Lütje, University of Hannover, Germany
}

Discussion paper No. 297

May 2004

ISSN 0949-9962

\begin{abstract}
Based on a questionnaire survey the paper distinguishes between herding asset managers who try to be good and non-herding asset managers who try to be better than their competitors. It provides evidence for reputational herding and discusses herding managers' working effort, preferred sources of information and investment horizon. Additionally, their risk taking behavior including their investment behavior in short-term tournament scenarios is analyzed. It is found that herding managers assess themselves as generally more risk averse than non-herding managers, but in the tournament they are willing to take more risk. This finding is ascribable to their fear of falling out of the herd.
\end{abstract}

JEL classification: G 14, G 23

Keywords: Institutional investors, herding, risk aversion, tournament hypothesis

I would like to thank Michael Melvin and Lukas Menkhoff for helpful comments as well as the German Investment and Asset Management Association 'BVI' for its very useful supporting letter. Financial support by the 'Wissenschaftsförderung der Sparkassen-Finanzgruppe e.V.', the research promotion arm of the German savings bank organization, is gratefully acknowledged.

Department of Economics, University of Hannover, Königsworther Platz 1, 30167 Hannover, Germany, luetje@gif.uni-hannover.de 


\section{To Be Good or To Be Better: Asset Managers' Attitudes Towards Herding}

\section{Introduction}

Institutional investors, such as investment funds, insurance companies and others, have become the dominant group in international financial markets during the past decades. They take advantage of comparatively low transaction costs and the opportunity of balanced portfolio diversification. Nevertheless, as empirical studies show, they mostly fail to achieve the market developments; no matter what kind of fund is managed - mutual fund or pension fund (see Malkiel, 1995, and Lakonishok et al., 1992), nor which period is considered - the postwar period or nowadays (see Jensen, 1968, Carhart, 1997, and Kempf and Griese, 2003). These results are astonishing, because asset managers are sophisticated, experienced market players who obtain valuable information about the economies and financial markets from professional research activities. So, one has to question why does their active portfolio management often not pay off? Malkiel (2003) ascribes this observation to additional expenses of active management (e.g. higher management fee) compared to passive strategies. However, another possible explanation for weaker performance is that asset managers could show inadequate working effort as they receive insufficient incentives. This paper provides evidence that some asset managers tend to strategic behavior of following the herd, which is connected with significantly less working effort than others.

Institutional investors act in a principal agent framework as agents when managing funds that belong to private or corporate clients, who can be considered as their principals. There is a conflict of interests as the clients demand attractive riskadjusted performance, whereas the asset managers - who naturally are effort averse - are more concerned about an adequate compensation for their working effort [explicit incentive] on the one hand and an adequate development of their professional career [implicit incentive] on the other hand. Managers should care for their reputation in the labor market as it might have an effect on their remuneration later in their career (see e.g. Fama 1980, Lazear and Rosen 1981, and Holmström 1999). Holmström and Ricart i Costa (1986, p. 856) find that reputational (career) concerns are more central than effort aversion in explaining incongruities in risk preferences between managers and owners or superiors. In order to make the asset 
managers act with best effort as desired by their principals, their investment performance is commonly assessed in relation to a benchmark - typically their peer group (see e.g. Lakonishok et al., 1992, and Maurer, 1998). But this also affords the opportunity for strategic behavior: By choosing his effort level an asset manager can "try to be good", i.e. equally good as his peers, or he can "try to be better", i.e. outperform the peer group. Respective behavioral strategies are herding for managers who (only) try to be equally good as their peers and non-herding for managers who try to be better. Here, non-herding should comprise both, anti-herding (i.e. observing the herding and doing the opposite) on the one hand and ignoring the herd on the other hand.

The opportunity for strategic behavior by means of herding has relevant macroeconomic implications. Froot et al. (1992) show that herding reduces efficiency of prices (see also Shiller, 2003). Moreover, this behavior increases the danger of contagion of financial crises (see e.g. Chari and Kehoe, 2003, Borensztein and Gelos, 2003, and Calvo and Mendoza, 2000). Due to these negative consequences it is important to know possible triggers of herd behavior.

Among other explanations (for a discussion see Bikhchandani and Sharma, 2001) reputational concerns seem to be the most important and strongest rational motives for apparently and stable herd behavior (Hirshleifer and Teoh, 2003). The theoretical background of reputational herding is ascribable to Keynes' (1936, p. 158) argumentation that "it is better for reputation to fail conventionally than to succeed unconventionally". Scharfstein and Stein (1990) follow this view and argue that an unfavorable decision affects the decision makers' reputation significantly less negatively when others made the same mistake as well. As a result, they ignore substantial private information but copy the action of the former for reputational reason. Accordingly, herding asset managers are able to "share the blame" and "hide in the herd" when their investment decisions emerge as being unprofitable (see also Devenow and Welch 1996). Additionally, Pally (1995) explains herding based on the principle of "safety in numbers". Chevalier and Ellison (1999) analyze the investment behavior of professional asset managers and they confirm that reputational career concerns can induce herding. They find that younger managers who typically have stronger career concerns as they have a longer working life ahead deviate less from the average decision of the herd. Moreover, hire and fire is a typical personnel policy in professional asset management. As younger managers are more at risk to be fired 
for bad performance than seniors, they tend to herd. Arora and Ou-Yang's (2001) empirical results confirm that the tendency to herding decreases with the manager's age. Similarly, Hong et al. (2000) as well as Lamont (2002) find that inexperienced forecasters deviate less from the consensus forecasts, but when they become older and more established they tend to make bolder forecasts to manipulate assessments of their ability.

Unfortunately, it is not only difficult to discriminate spurious from intentional herding, but particularly to identify reputational herding. The inconsistent evidence of herding (see discussion in Sias, 2004) and especially the lack of a measure of reputational herding motivates us to pursue a questionnaire survey as an alternative approach. We asked professional asset managers by questionnaire concerning their motivation and investment behavior and distinguish between decision makers who "try to be good" and those who "try to be better". By doing so, we avoid the problematic use of a proxy. This kind of method enables a systemic consideration of personal viewpoints and intentional behavior in specific situations and is therefore able to detect reputational herding. It is established as a way to analyze financial markets, being used by Shiller (1989), Blinder (2000) and Strong and Xu (2003) among others. Our survey provides evidence for the existence of reputational herd behavior. Herding managers show less working effort, focus on shorter investment horizons and prefer the use of non-fundamental information. Furthermore, we find that they are generally more risk averse, but in short-term tournament scenarios they are willing to take more risk as they apparently fear of falling out of the herd.

The remainder of the paper is structured as follows. Section 2 presents the methodology and design of the survey in professional asset management. Section 3 comprehends a discussion about different views on reputational herd behavior. In Section 4 we initially focus on managers' working effort, preferred sources of information and investment horizons. Then, in Section 5, we analyze their risk taking behavior including short-term alteration in a tournament situation. Finally, Section 6 concludes the paper.

\section{Survey methodology and design}

A questionnaire survey being conducted with asset managers in Germany in 2003 provides the data set for the analyses here. The survey is motivated by institutional investors' influence and role in international investment markets and 
focuses on the personal viewpoints, perceptions and investment behavior of professional asset managers. As we developed the short questionnaire, we had to consider that the quality and significance of the answers given critically depend on the selection of possible questions and their correct formulation. Therefore, we discussed draft versions of the questionnaire with professional asset managers in numerous personal interviews between February and March 2003 in order to avoid misinterpretations. The interviews could contribute to specify relevant hypotheses from the economic literature and to assess their applicability for a written survey. Pretests confirmed the questionnaire's applicability. Moreover, we had to bear in mind that the recipients will be more willing to fill in the questionnaire the shorter it is.

During the period of April to June 2003 the fund management companies in Germany were repeatedly contacted to participate in the survey. The German investment association 'BVI Bundesverband Investment und Asset Management e.V.' supported our research project with a letter of recommendation to all its member firms. In total, we received 263 filled in questionnaires from professional asset managers. Sustained following up by mail, email and telephone was necessary to achieve such a large sample size. As the survey was conducted by mail as well as by email we do not report a response rate on the whole number of questionnaires the asset managers received, because a lot of asset managers forwarded the questionnaire to their colleagues by email attachment. We rather emphasize the participation rate of fund management companies which is $77.3 \%$. In detail, we sent questionnaires to 66 member firms of the BVI with major investment segments in equities, bonds and money market, respectively and fund managers of 51 different companies participated in the survey. Strategic answers are not expected due to guaranteed anonymity of participants. With regard to that remarkable participation rate, the large data sample seems to be suitable to truthfully represent the personal viewpoints, perceptions and investment behavior of fund managers in Germany. Table 1 confirms the representativeness of the collected data sample: the null hypothesis of no difference between the structure of the data set and that of the German asset management industry cannot be rejected. Bigger investment companies typically employ more asset managers and have a higher market impact than smaller ones. This higher importance is also reflected in the data set, as asset managers of bigger companies participated significantly more in the survey (see Table 1). Moreover, the typical personal characteristics of the surveyed asset 
managers are in line with the findings in current surveys in German asset management, e.g. Arnswald (2001) or Brozynski et al. (2004). For detailed information see Lütje and Menkhoff (2004).

\section{Survey findings on reputational herding}

First of all, we realize that herding is not only a theoretical problem, but definitively exists in practice. By measuring the level of institutional herding directly (without the problematic use of a proxy) the present analysis adds to the empirical literature on herding. The survey shows that institutional herding is perceived by a great majority of asset managers. Numerous interviews made sure that asset managers comprehend only intentional behavior as herding. Figure 1 illustrates that $91.3 \%$ of the surveyed asset managers perceive institutional herding, since they agree with statement $[\mathrm{A}]$ that "herding is observable amongst professional asset managers."

Following the arguments by Chevalier and Ellison (1999) who confirm a positive correlation between asset managers' career concerns and herd behavior, we test the following hypothesis:

H1: Asset managers believe that herding benefits the career.

Figure 1 also shows that only $40.1 \%$ believe that herd behavior benefits the asset manager's career, whereas $59.9 \%$ disagree to the respective statement $[B]$. Taking this general market view into consideration, we should rather reject $\mathbf{H 1}$. However, we have to point out that this is the aggregated view of the whole industry. Do asset managers who follow the herd themselves have a different opinion regarding the influence of herding on managers' reputation and career, respectively? To analyze this, we additionally take into account their assessment of statement [C] "I generally follow the trend." As the figure illustrates there are approximately as many asset manager that admit to follow the trend (50.2\%) as others who do not $(49.8 \%)$. Why do approximately half of the asset managers tend to follow the trend? We consider their subjective view on how herding affects the asset managers' career to unveil their motivation. We find that asset managers who follow the trend significantly have a stronger belief that herding benefits their career compared to non-herding asset managers. The Spearman rank correlation in Table 2 substantiates this 
relation. Thus, we conclude that herding is (at least partly) triggered by asset managers' career concerns, since they rather believe in beneficial effects of such investment behavior. While from the aggregated market view one should rather reject $\mathbf{H 1}$, the subjective point of view of herding asset managers, however, somewhat supports this hypothesis.

\section{Herding managers' working effort, preferred source of information and investment horizon}

\subsection{Herd behavior and working effort}

Due to the principal agent problems in professional asset management there is a gap between the working effort level targeted by the asset managers and that desired by their clients. A possible and widely used mechanism to reduce the disparity is the relative performance measurement in relation to a benchmark (normally the performance of a peer group). But in this situation an asset manager faces the opportunity of strategic behavior. As a herding manager does not "try to be better" than his peers, we expect him to show less working effort than non-herding asset managers who by definition "try to be better". It seems to be plausible that nonherding asset managers show more working effort, since the wish "to be better" typically claims to be more ambitious.

H2: Herding managers show less working effort than non-herding managers.

We measure managers' working effort by their average working hours per week (being typically 46-50 hours, see Figure 2) and find that herding managers exhibit significantly less working effort than non-herding ones. The Spearman rank correlation in Table 3 confirms H2. As the asset manager's working effort cannot be observed by his clients (see Golec, 1992 p. 82) and only partly by his superiors, he has some opportunity to reduce working effort and execute hidden action. However, asset managers are predominantly evaluated and performance-related paid by means of (relative) fund performance (see Gehrig et al., 2004). The latter does not necessarily reflect true management achievement (see also Starks, 1987, p.19, and Heinkel and Stoughton, 1994, p.354). 


\subsection{Herd behavior and use of information}

After providing evidence for institutional herding in Section 3 we consider the information which herding managers typically use. Scharfstein and Stein (1990) conclude that decision makers ignore substantive private information they possess, because they will be more favorably evaluated if they follow the decisions of others. Therefore, we expect identified herding managers to focus on non-fundamental information - especially the investment decisions of other market players.

H3: Herding managers focus on non-fundamental information.

The analysis provides evidence that fundamentals and their discussion with colleagues are the most important sources of information for asset managers, followed by technical analysis. However, we also find that herding asset managers typically base their investment decisions comparatively more on technical analysis, investment decisions of other market players and the statements of opinion leaders of the industry in relation to non-herding managers. Moreover, they ascribe significantly less importance to fundamental information and serious discussions with their colleagues. For more details see Spearman rank correlations in Table 4. In addition, the multinomial setting of an ordered probit regression discloses that following the trend is significantly driven by using technical analysis and taking into account statements of industry's opinion leaders. In contrast, using fundamental information significantly lowers trend following behavior. These findings confirm $\mathbf{H 3}$. This kind of selective use of information implies negative macroeconomic consequences as it may drive securities prices away from fundamental equilibria. In this manner, our findings support the results in Froot et al. (1992) that herding reduces efficiency of prices. Apart from that, we find that non-herding asset managers base their investment decisions especially on fundamental information and its discussion with their colleagues, whereas technical analysis, investment decisions of other market players and the statements of opinion leaders within the industry are significantly less important. This behavior would help to improve market efficiency as it drives security prices towards the fundamental equilibria. The preference for the mentioned kind of information seems to be plausible for non-herding managers who "try to be better": If you are too focused on what the other market players do and what opinion leaders say, you can at most be as good as your peers are. Non- 
herding asset managers who "try to be better" concentrate on fundamental facts and discuss their viewpoints with their colleagues.

\subsection{Herd behavior and investment horizon}

We already realized that herding managers predominantly base their investment decisions on technical analysis which is typically used for short-term forecasting horizons (see evidence in Gehrig and Menkhoff, 2003). Consequently, they are expected to have a shorter investment horizon than non-herding managers. Another explanation for this assumption is that herding managers are typically more benchmark oriented and as the fund performance will regularly be assessed in the short term (see Marsh, 1992, and Lakonishok et al., 1991) they should focus on this horizon. It seems to be plausible that asset managers tend to short term horizon: Imagine they actually possess valuable information for promising long term performance that recommends a deviation from the current market view. Then, the resulting investment strategy is expected to be impeded by third parties who due to short term performance evaluation contradict such deviation (see Menkhoff, 2002). Baker's (1998) interview study conducted with fund managers in the United Kingdom as well as Arnswald's (2001) questionnaire survey of German fund managers provide evidence for their short term orientation.

H4: Herding managers focus on shorter investment horizons than non-herding manager.

To test the hypothesis that herding managers are even more short term oriented, we asked the asset managers what their personal forecasting horizon is when making investment decisions. We offered five response categories from "days" to "years" and calculate a mean forecasting horizon of 6-12 months. The survey also provides evidence that herding managers significantly focus more on shorter investment horizons than non-herding managers. This result in Table 4 confirms $\mathbf{H} 4$.

One has to question whether this orientation is in line with their clients' preferred investment horizon. In contrast to asset managers, their clients are rather long term oriented, e.g. for retirement provisions. Here the principal agent problems become obvious as the problem of performance justification induces asset managers' short term horizon. However, Marsh (1992) argues that their short term actions often reflect 
long term views. Furthermore, short term horizon would also appear in myopic loss aversion. This behavioral pattern is the combination of a greater sensitivity to losses than to gains and a tendency to frequent performance evaluation (see Thaler et al., 1997). Thus, in Section 5.2 we will discuss whether herding managers who focus on shorter investment horizon also have a stronger loss aversion.

\section{Herding managers' risk taking behavior}

\subsection{Herd behavior and risk aversion}

Herding asset managers are able to hide in the herd and to share the blame when their investment decisions emerge as being unprofitable (Scharfstein and Stein, 1990, and Devenow and Welch, 1996). Additionally, Pally (1995) explains herding based on the principle of safety in numbers. Thus, we assume herding asset manager to be more risk averse. This view is in line with the finding in Gümbel (2003) that investors herd in their asset allocation, when managers are sufficiently risk averse.

H5: Herding managers are more risk averse than non-herding managers.

Asking the asset managers to self-assess their attitude towards financial risk allows us to test this hypothesis. Accordingly, we asked them to complete the following sentence: "In respect of professional investment decisions, I mostly act...". The response categories range from "very risk averse" to "little risk averse". While the survey unveils that asset managers self-assess as "medium risk averse" on average, it also provides significant evidence that herding managers regard themselves as more risk averse (see Table 5). But we have to emphasize that this self-assessment can possibly deviate from actual risk taking behavior. So, we also consider their risk taking behavior in a simulated bet: "Imagine someone offers you a bet and the odds are fifty-fifty. You will have to pay $€ 1,000$ from your personal account if you lose. What would be the minimum amount you would expect to win to lure you into accepting the bet?" According to Table 5 we suppose that herding managers are more risk averse as they demand a higher possible win to accept the bet. We find a positive correlation between the demanded amount and following the trend. However, this result is not statistically significant. Hence, we take a closer look 
on their risk taking behavior and consider behavioral biases - more precisely their loss aversion and disposition effect.

\subsection{Herd behavior and biased risk-taking behavior}

a) Loss aversion

According to Kahneman and Tversky's (1979) prospect theory, loss aversion implies being more sensitive to losses than to gains. This can be concluded from an S-shaped value function, being convex for losses and concave for gains. Loss aversion in terms of higher sensitivity to losses becomes obvious in the steeper slope below the reference price (typically the purchase price). Tversky and Kahneman (1992) come to the conclusion that individuals weight losses approximate 2.25 times as strongly as gains. We expect herding managers to have a higher loss aversion than non-herding ones - not only as they fear to fall out of the herd when cutting losses. Another reason is that they are more risk averse (see evidence provided in Section 5.1) and Schmidt and Zank (2002) argue that the definition of loss aversion has analogies with those of risk aversion.

H6: Herding managers are more loss averse than non-herding managers.

The simulated bet in Section 5.1 shows that asset managers have a smaller loss aversion compared to non-professional individuals as considered in Tversky and Kahneman (1992). Asset managers median answer indicates that losses are weighted (only) 1.75 times the gains. ${ }^{1}$ The higher minimum amount demanded to accept the bet somewhat indicated a higher loss aversion of herding managers in relation to non-herding managers. To substantiate this assumption the asset managers were asked to assess the following statement: "In case of loss positions in my portfolio I generally wait for a price rebound instead of selling those securities." Even if only $42.1 \%$ of all managers agree with that statement, we find that herding managers significantly agree to a greater extent with it. In Table 5 the Spearman rank correlation confirms that they are indeed more loss averse and it hence supports $\mathbf{H 6}$. While loss aversion only considers the investment behavior regarding losses, the disposition effect also captures the behavior concerning profits.

\footnotetext{
${ }^{1}$ All other coefficients as per Kahneman and Tversky (1992).
} 


\section{b) Disposition effect}

Shefrin and Statman (1985) define the disposition to ride losers too long (i.e. loss aversion) and to sell winners too early as disposition effect. Odean (1998) finds empirical evidence for this phenomenon. Weber and Camerer (1998) confirm the disposition effect with experiments and ascribe this behavior to people's reluctance to admit wrong investment decisions ex post. Shapira and Venezia's (2001) research provides empirical evidence that both, independent investors and professional asset managers exhibit the disposition effect, albeit it is stronger for the independent. Due to the fact that herding managers are more loss averse than non-herding managers (see evidence discussed above) we expect them to have a stronger disposition effect, too.

H7: Herding managers make investment decisions with stronger disposition effect than non-herding managers.

To test this hypothesis, we asked the asset managers to comment on the following statement: "I prefer to take profits instead of cutting losses when I am confronted with unexpected liquidity demands." It is found that only $37.8 \%$ of the surveyed managers agree to have such a disposition effect. The Spearman rank correlation provides evidence that herding managers agree significantly more with that statement (see Table 5). This demonstrates that they have a stronger disposition effect and hence supports $\mathrm{H} 7$.

Summing up so far, we identified different characteristics of herding versus nonherding asset managers. The multivariate analysis in Table 6 unveils that, among all items considered, herding is predominantly driven by a specific use of information sources and risk taking behavior: Herding managers prefer the use of technical analysis and pay less attention to fundamental information. Moreover, they assess themselves as more risk averse which also becomes obvious in their stronger loss aversion. We realized that herding managers have a significantly different risk taking behavior than non herding ones. We also realized that they tend to short term horizon (even if it is no main driver of herding as the multivariate analysis shows). In order to consider both aspects jointly, we analyze their risk taking behavior in the short term perspective in Section 5.3. For this purpose we simulate tournament 
scenarios professional asset managers typically face near the end of the period. Do herding managers possibly change their risk-taking behavior during the year?

\subsection{Herd behavior in the tournament}

In the literature there are different opinions, how and in what direction (higher or lower risk level) the risk taking behavior is influenced by performance incentives. In fact, there is an interesting discussion about the so called "tournament effect". Brown et al. (1996) argue that the tournament structure of the mutual fund industry influences the asset managers to vary the risk level of their portfolios near the end of the valuation period. Particularly, successful performing funds tend to lock in, while losing funds tend to gamble. Arora and Ou-Yang (2001) argue that the risk manipulation is definitely more influenced by this tournament effect than by manager's career concerns. The finding that past performance is negatively related with changes in risk can be ascribed to the coincidence of two circumstances. First, the incentive of asset based fees (i.e. fees in per cent of assets under management) in the investment management industry makes the asset managers compete with each other for clients' assets. Second, Sirri and Tufano (1998) provide evidence that investors react asymmetrically to fund performance. They show that high performing funds receive large inflows, but underperforming funds are not equally penalized with outflows. However, Busse (2001) questions the temporal coherence with the managers' strategic year end risk alteration as tournament effect; because mutual fund performance is widely reported daily and cash flows accrue to funds throughout the year. Chevalier and Ellison (1997) confirm that underperforming funds tend to gamble to catch the market whereas funds that are a few points ahead of the benchmark tend to lock in. However, they also find that even outperforming funds tend to gamble to become a top performer, if they are not only a few points, but well ahead of the benchmark.

Busse (2001) examines the validity of the tournament hypothesis for the behavior of US mutual fund managers based on daily observations. His findings contradict prior evidence based on monthly evidence as found by Brown et al. (1996), i.e. the tournament effect disappears with daily data. He considers two possible explanations as responsible for the conflicting evidence (see also Goriaev et al. (2003). On the one hand, auto-correlation in daily fund returns biases volatility estimates used in empirical tests of the tournament hypothesis until then. On the 
other hand, cross-correlation in mutual fund returns invalidates the independence assumption underlying the standard statistical tests for the tournament hypothesis. He argues that the evidence in favor of the tournament hypothesis based on monthly fund returns disappears when empirically accounting for either of these effects. By doing so, he finds that fund's intra-year change in risk arises rather from changes in the volatility of common stock market risk factors as it is not related to changing factor exposures or residual risk. Thus, he concludes very little of risk alteration is attributable to deliberate actions of the fund manager.

According to this somewhat inconclusive evidence of the tournament effect, we will test the tournament hypotheses in two steps. First, we will examine whether the tournament structure of the mutual fund industry makes that asset managers tend to vary the risk level near the end of the period. If this is the case, we will take a closer look and test secondly in what direction the risk level will be changed in two different performance scenarios. Our survey approach has the advantage that we ask the asset manager directly about his preferred action. Hence, we will be able to comment on Busse's (2001) objection that very little of risk alteration is supposed to be attributable to the 'deliberate actions' of the fund manager.

H8: Asset managers do not always keep their strategy until the end of the period.

H9: Near the end of the period, outperformers tend to lock in.

H10: Near the end of the period, underperformers tend to gamble to catch up.

These hypotheses are predominantly based on the findings in Brown et al. (1996). They also refer to the evidence in Chevalier and Ellison (1997); however, we have to assume here that the fund performance is only "a few points ahead" of the benchmark, but not "well ahead" to bring $\mathbf{H} 9$ in line with Chevalier and Ellison's findings. From our point of view, Chevalier and Ellison's differentiation is not practicable in a written survey as the separation between "a few points ahead" and "well ahead" would individually be interpreted, whereas the differentiation between under- and outperformance is consistently understood.

The results confirm that asset managers do not always keep their strategy until the end of the period: Table 7 shows that only $51.4 \%$ of the asset managers retain their chosen investment strategy if they deviate from the benchmark (in both scenarios) near the end of the period, whereas $48.6 \%$ change their risk behavior in 
case they underperformed and/or outperformed the benchmark so far. This finding seems to confirm $\mathbf{H 8}$ since a comparatively high share of asset managers would 'intentionally' change the chosen risk level. The result somewhat overrules Busse's (2001) objection that very little of risk alteration is attributable to the managers' deliberate actions. With regard to the conclusion that nearly half of the surveyed asset managers are willing to vary the risk level near the end of the period, we want to find out, in which direction they vary the risk level in the respective scenario. So, we consider the two scenarios separately.

Accordingly, Table 7 illustrates that $65.5 \%$ of all asset managers would keep their strategy when the benchmark is outperformed so far, while $33.7 \%$ would decrease the relative risk level to lock in performance and $0.8 \%$ would increase the relative risk level to become a 'top performer'. This bias towards taking less risk in case of outperformance confirms H9. On the other hand, when the benchmark is underperformed so far, $69.0 \%$ of all asset managers would keep their strategy, while $21.8 \%$ would decrease the relative risk level to avoid further deficits and $9.1 \%$ would increase the relative risk level to reach the benchmark. This survey finding does not confirm $\mathrm{H10}$, because in this scenario there are more asset managers who decrease the risk level than the ones who start to gamble. However, compared to the scenario of outperformance, here we find more gamblers.

Summing up, the survey provides evidence for the behavior as expected by the tournament hypothesis when the benchmark is outperformed so far, but rather not when it is underperformed until now. How can we explain this finding? A possible reason for the unexpected behavior in the underperformance scenario could be that herding and non-herding managers behave differently and, therefore, the tournament effect might be biased. Does the separate subgroup consideration unveil different tournament behavior and for that reason explain why the tournament hypothesis should be rejected in the case of underperformance? The following analysis will confirm this speculation.

Since a herding asset manager is typically focused on what the herd does, we assume that he considers the (average) performance of the herd as his relevant "benchmark". So, we argue that a herding asset manager intends not to fall out of the herd when he underperforms his "benchmark" so far. In that case, he should tend to increase the risk level to catch up to the average performance of the herd. 
H11: Herding asset mangers tend to increase the risk-level near the end of the period to a larger extent than non-herding ones, if they underperformed the benchmark so far.

Regarding the underperformance scenario, there we find a strongly significant difference between the two groups, as the Mann-Whitney U-Test in Table 7 clearly shows. This result emphasizes and confirms the finding as already presented in the distribution of answers that herding asset managers are more willing to take more risk when they fall short. When the benchmark is underperformed so far, $64.8 \%$ of the herding asset managers would keep their strategy, while $21.9 \%$ would decrease the relative risk level to avoid further deficits and $13.3 \%$ would increase the relative risk level to reach the benchmark. Considering non-herding asset managers there are $73.8 \%$ that would keep their strategy, $22.1 \%$ that would decrease the chosen risk level but only $4.1 \%$ that would increase the risk level. This survey finding that herding managers are about three times more willing to take more risk when they underperform the benchmark so far seems to confirm H11. So, the survey provides evidence that asset managers who tend to follow the herd are generally more risk averse (see Section 5.1), but in the tournament - i.e. near the end of the period they are willing to take more risk. We ascribe this finding to their fear of falling out of the herd when they perform worse. The combination of herding managers' short term horizon (see evidence in Section 4.3) and their loss aversion (see evidence in Section 5.2) seems to indicate myopic loss aversion (see Thaler et al. 1997). Much more work has to be done to justify this assumption.

\section{Conclusions}

The study examines German asset managers' attitudes towards herd behavior based on a questionnaire survey of 263 responses. It considers herding as strategic behavior to be evaluated as good as the peer group, whereas non-herding is regarded as the attempt to be better. The paper achieves the disclosure of significant differences between herding and non-herding managers in respect of working effort, preferred use of information, investment horizon and risk taking behavior.

First of all, the study provides evidence that institutional herding actually exists. It is perceived to a large extent by a great majority of asset managers. This kind of behavior is (at least partly) ascribable to asset managers' reputational and career 
concerns: Herding managers believe in benefits of herd behavior for their career. As their attitude is to be as good as their peers are, it is not surprising that they show less working effort than non-herding asset managers who "try to be better". Herding managers' investment behavior drives prices away from fundamental equilibriums, because they significantly use more non-fundamental information and focus on shorter investment horizons. Furthermore, they are generally more risk averse and loss averse and their investment decision is more biased by a disposition effect. Interestingly, the survey provides strong evidence that herding managers are generally more risk averse, but in the tournament they are willing to take more risk. We ascribe this finding to their fear of falling out of the herd.

\section{References}

Arnswald, Torsten (2001), Investment Behaviour of German Equity Fund Managers, An Exploratory Analysis of Survey Data, Deutsche Bundesbank Discussion Paper 08/01, Frankfurt.

Arora, Navneet and Hui Ou-Yang (2001), Explicit and Implicit Incentives in a Delegated Portfolio Management Problem: Theory and Evidence, Working Paper, University of North Carolina.

Baker, Mae (1998), Fund Managers' Attitudes To Risk and Time Horizons: The Effect of Performance Benchmarking, European Journal of Finance, 4, 257-278.

Bikhchandani, Sushil and Sunil Sharma (2001), Herd Behavior in Financial Markets: A Review, IMF Staff Papers, 47:3, 279-310.

Blinder, Alan S. (2000), Central Bank Credibility: Why Do We Care? How Do We Build It?, American Economic Review, 90:5, 1421-1431.

Borensztein, Eduardo R. and R. Gaston Gelos, A Panic-Prone Pack? The Behavior of Emerging Market Mutual Funds, IMF Staff Paper, 50:1, 43-63.

Brown, Keith C., W. V. Harlow and Laura T. Starks (1996), Of Tournaments and Temptations: An Analysis of Managerial Incentives in the Mutual Fund Industry, Journal of Finance, 51, 85-110.

Brozynski, Torsten, Lukas Menkhoff and Ulrich Schmidt (2004), The Use of Momentum, Contrarian and Buy-\&-Hold Strategies: Survey Evidence from Fund Managers, Working Paper, University of Hannover.

Busse, Jeffrey A. (2001), Another Look at Mutual Fund Tournaments, Journal of Financial and Quantitative Analysis, 36:1, 53-73. 
Calvo, Guillermo A. and Enrique G. Mendoza (2000), Rational Contagion and the Globalization of Securities Markets, Journal of International Economics, 51, 79-113.

Carhart, Mark M. (1997), On Persistence in Mutual Fund Performance, Journal of Finance, 52:1, 57-82.

Chari, V. V. and Patrick J. Kehoe (2003), Financial Crises as Herds: Overturning the Critiques, NBER Working Paper, No. 9658. Cambridge, Mass.

Chevalier, Judith A. and Glenn Ellison (1999), Career Concerns of Mutual Fund Managers, Quarterly Journal of Economics, 114, 389-432.

Chevalier, Judith A. and Glenn Ellison (1997), Risk-Taking by Mutual Funds as a Response to Incentives, Journal of Political Economy, 105:6, 1167-120.

Devenow, Andrea and Ivo Welch (1996), Rational Herding in Financial Economics, European Economic Review, 40, 603-615.

Fama, Eugene F. (1980), Agency Problems and the Theory of Firms, Journal of Political Economy, 88, 288-307.

Froot, Kenneth A., David S. Scharfstein and Jeremy C. Stein (1992), Herd on the Street: Informational Inefficiencies in a Market with Short-term Speculation, Journal of Finance, 47, 1461-1484.

Gehrig, Thomas, Torben Lütje and Lukas Menkhoff (2004), Incentives and Asset Managers' Behavior: Cross-Atlantic Evidence, Working Paper, University of Hannover.

Gehrig, Thomas and Lukas Menkhoff (2003), Extended Evidence on the Use of Technical Analysis in Foreign Exchange), International Journal of Finance and Economics, forthcoming.

Golec, Joseph H. (1992), Empirical Tests of a Principal-Agent Model of the Investor Investment Advisor Relationship, Journal of Financial and Quantitative Analysis, 27, 81-95.

Goriaev, Alexei P., Theo E. Nijman and Bas J. M. Werker (2003), Yet Another Look at Mutual Fund Tournaments, Working Paper, Tilburg University.

Gümbel, Alexander (2003), Herding in Delegated Portfolio Management: When is Comparative Performance Information Desirable?, European Economic Review, forthcoming.

Heinkel, Robert and Neal M. Stoughton (1994), The Dynamics of Portfolio Management Contracts, Review of Financial Studies, 7, 351-387.

Hirshleifer, David and Siew Hong Teoh (2003), Herd Behaviour and Cascading in Capital Markets: a Review and Synthesis, European Financial Management, 9:1, 25-66. 
Holmström, Bengt (1999), Managerial Incentive Problems: A Dynamic Perspective, Review of Economic Studies, 66:1, 169-182.

Holmström, Bengt and Joan Ricart i Costa (1986), Managerial Incentives and Capital Management, Quarterly Journal of Economics, 101:4, 835-860.

Hong, Harrison, Jeffrey D. Kubik and Amit Solomon (2000), Security Analysts' Career Concerns and Herding of Earnings Forecasts, RAND Journal of Economics, 31:1, 121-144.

Jensen, Michael C. (1968), The Performance of Mutual Funds in the Period 1945-64, Journal of Finance, 23, 386-416.

Kahneman, Daniel and Amos Tversky (1979), Prospect Theory: An Analysis of Decision Under Risk, Econometrica, 47, 263-291.

Kempf, Alexander and Knut Griese (2003), Lohnt aktives Fondsmanagement aus Anlegersicht?, Zeitschrift für Betriebswirtschaft, 73:2, 201-224.

Keynes, John Maynard (1936), The General Theory of Employment, Interest and Money, London: MacMillan.

Lakonishok, Josef, Andrei Shleifer, Richard H. Thaler and Robert W. Vishny (1991), Window Dressing By Pension Fund Managers, American Economic Review, 81, Papers and Proceedings, 227-231.

Lakonishok, Josef, Andrei Shleifer, Richard H. Thaler and Robert W. Vishny (1992), The Structure and Performance of the Money Management Industry, Brookings Papers on Economic Activity, Microeconomics, 339-391.

Lamont, Owen (2002), Macroeconomic Forecasts and Microeconomic Forecasters, Journal of Economic Behavior and Organization, 48:3, 265-280.

Lazear, E. and S. Rosen (1981), Rank-Order Tournaments as Optimum Labor Contracts, Journal of Political Economy, 89:5, 841-864.

Lütje, Torben and Lukas Menkhoff (2004), Fondsmanagement in Deutschland: Was denken und tun die Akteure?, Working Paper, University of Hannover.

Malkiel, Burton G. (1995), Returns from Investing in Equity Mutual Funds 1971 to 1991, Journal of Finance, 50, 549-572.

Malkiel, Burton G. (2003), Passive Investment Strategies and Efficient Markets, European Financial Management, 9:1, 1-10.

Marsh, Paul (1992), Short-termism, The New Palgrave Dictionary of Money \& Finance, edited by Peter Newman et al., London and Basingstoke: Macmillan, 446-453.

Maurer, Raimond (1998), Risikoanreize bei der Gestaltung erfolgsabhängiger Entlohnungssysteme für Kapitalanlagegesellschaften, Zeitschrift für betriebswirtschaftliche Forschung, 50, 507-530. 
Menkhoff, Lukas (2002), Institutional Investors: The External Costs of a Successful Innovation, Journal of Economic Issues, 36:4, 907-933.

Odean, Terrance (1998), Are Investors Reluctant to Realize Their Losses?, Journal of Finance, 53, 1775-1798.

Pally, Thomas I. (1995), Safety in Numbers: A Model of Managerial Herd Behavior, Journal of Economic and Behavior and Organization, 28, 443-450.

Scharfstein, David S. and Jeremy C. Stein (1990), Herd Behavior and Investment, American Economic Review, 80:3, 465-479.

Schmidt, Ulrich and Horst Zank (2002), Risk Aversion in Cumulative Prospect Theory, Working Paper, University of Manchester.

Shapira, Zur and Itzhak Venezia (2001), Patterns of Behavior of Professionally Managed and Independent Investors, Journal of Banking and Finance, 25, 1573-1587.

Shefrin, Hersh and Meir Statman (1985), The Disposition to Sell Winners Too Early and Ride Losers Too Long: Theory and Evidence, Journal of Finance, 40:3, 777-790.

Shiller, Robert J. (1989), Market Volatility. MIT Press, Cambridge, Mass.

Shiller, Robert J. (2003), From Efficient Markets Theory to Behavioral Finance, Journal of Economic Perspectives, 17:1, 83-104.

Sias, Richard W. (2004), Institutional Herding, Review of Financial Studies, 17:1, 165-206.

Sirri, Erik R. and Peter Tufano (1998), Costly Search and Mutual Fund Flows, Journal of Finance, 53, 1589-1622.

Starks, Laura T. (1987), Performance Incentive Fees: An Agency Theoretic Approach, Journal of Financial and Quantitative Analysis, 22, 17-32.

Strong, Norman and Xinzhong Xu (2003), Understanding the Equity Home Bias: Evidence from Survey Data, Review of Economics and Statistics, 85:2, 307-312.

Thaler, Richard H., Amos Tversky, Daniel Kahneman and Alan Schwartz (1997), The Effect of Myopia and Loss Aversion on Risk Taking: An Experimental Experiment, Quarterly Journal of Economics, 112, 647-661.

Tversky, Amos and Daniel Kahneman (1992), Advances in Prospect Theory: Cumulative Representation of Uncertainty, Journal of Risk and Uncertainty, 5, 297-323.

Weber, Martin and Colin F. Camerer (1998), The Disposition Effect in Securities Trading: An Experimental Analysis, Journal of Economic Behavior and Organization, 33, 167-184. 
TABLE 1. Comparison of the data sample with industry's structure

Structure of the German asset management industry (by assets under management)

Structure of the data sample (by assets under management)

$\mathrm{H}_{0}$ : no difference ${ }^{1)}$ $-0.669(0.503)$

Correlation ${ }^{2)}$ with company size

(by assets under management)

Number of answered questionnaires per company

$0.678^{* * *}(0.000)$

The market data is taken from on the preliminary annual report 2003 of the BVI.

1) The table gives the $z$-value of the Mann-Whitney U-Test with the p-value in parentheses.

2) The table gives the coefficient of the Pearson correlation with the $p$-value in parentheses. Asterisks refer to level of significance: ${ }^{*} 10 \%,{ }^{* *} 5 \%,{ }^{* *} 1 \%$.

\section{FIGURE 1. Perception of herding, career concerns and following the trend}

Statement $[\mathrm{A}] \quad$ "Herding is observable amongst professional asset managers."

Statement $[\mathrm{B}] \quad$ "Following the herd benefits the asset manager's career."

Statement [C] "I generally follow the trend."

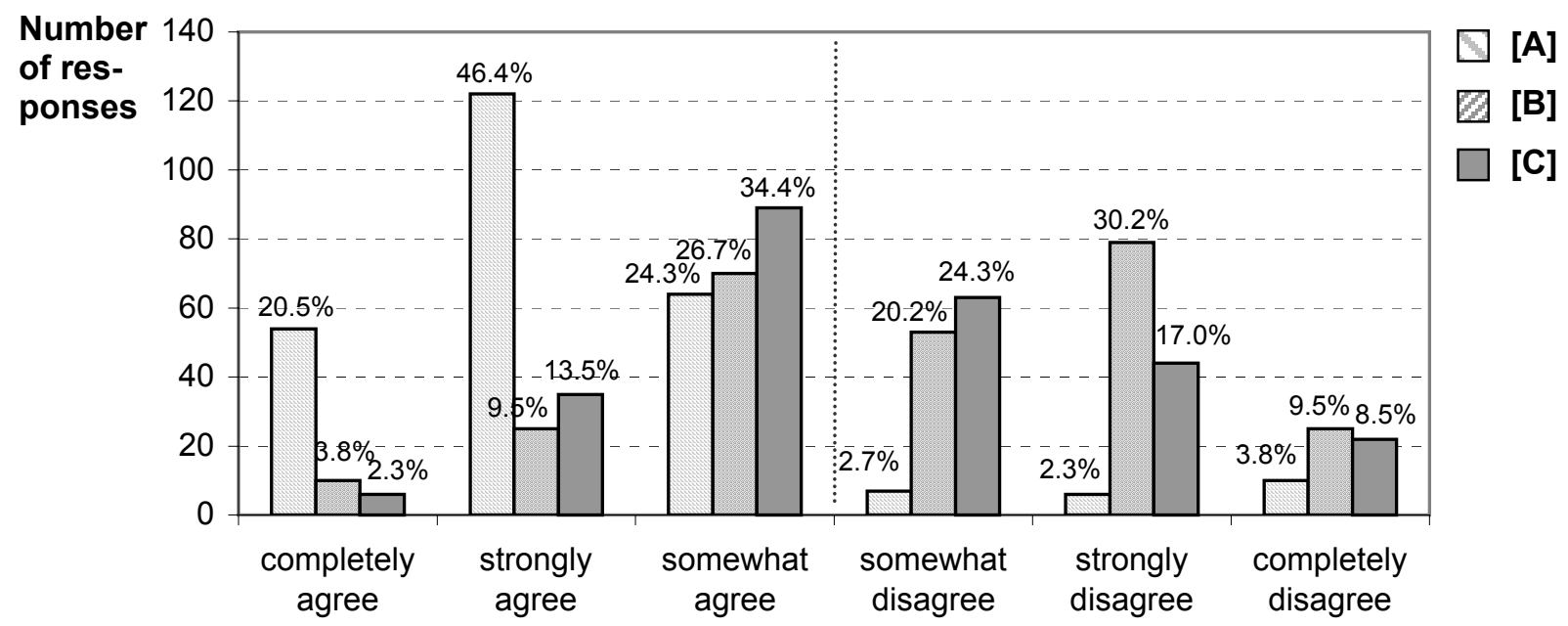




\section{TABLE 2. Herd behavior and career concerns}

"Following the herd benefits the asset manager's career." Six answering categories from "completely agree" (coded as 1) to "completely disagree" (coded as 6).

$\begin{array}{cc}\text { Share of } & \begin{array}{c}\text { Spearman rank correlation } \\ \text { agreement }\end{array}{ }^{1)} \\ \text { with following the trend }\end{array}$

Herding benefits career

$40.1 \%$

$0.276^{* * *}(0.000)$ [258]

1) The share of agreement is calculated as aggregated distribution to the answer categories 1-3.

2) The table gives the coefficient of the Spearman rank correlation with the p-value in parentheses and the number of responses in squared brackets.

Asterisks refer to level of significance: ${ }^{*} 10 \%,{ }^{* *} 5 \%,{ }^{* * *} 1 \%$.

\section{FIGURE 2. Working effort in asset management business}

Question "Average working hours per week?"

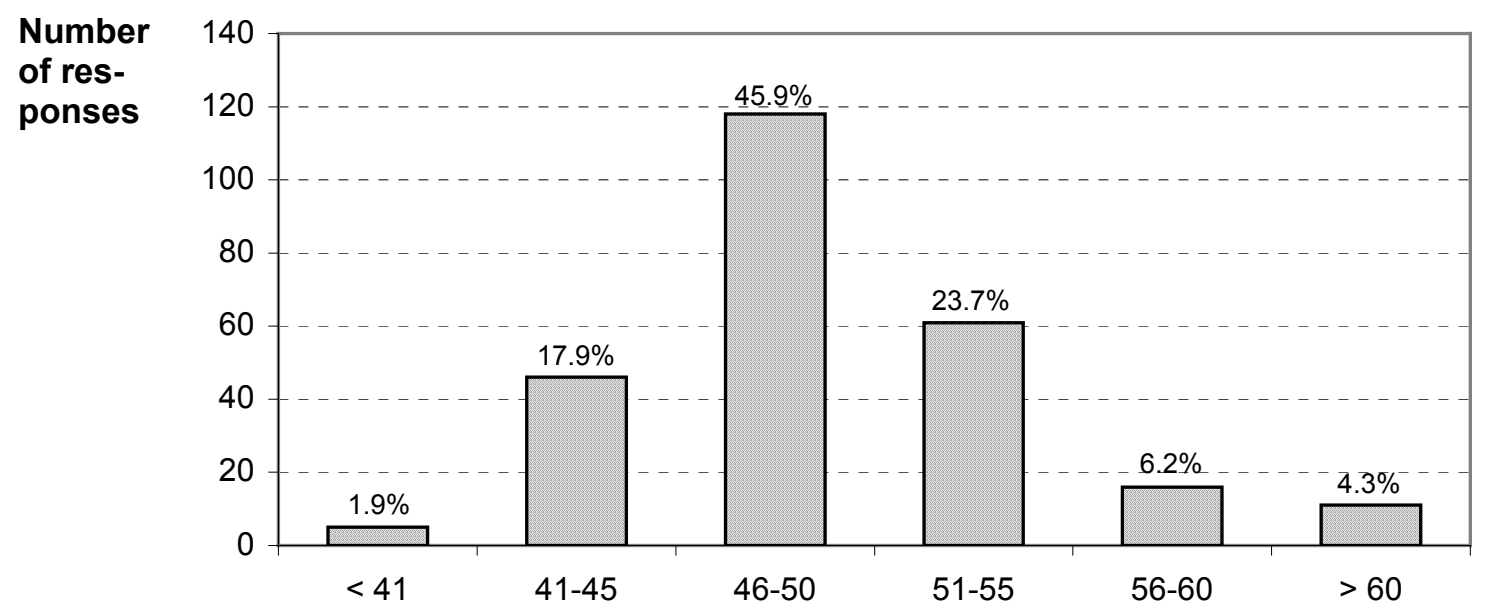

\section{TABLE 3. Herd behavior and working effort}

"Average working hours per week?" Six answer categories ranging from "<41" (coded as 1 ) up to "> 60" (coded as 6).

\begin{tabular}{|c|c|c|}
\hline & $\begin{array}{l}\text { All managers' } \\
\text { mean answer }\end{array}$ & $\begin{array}{l}\text { Spearman rank correlation }{ }^{1)} \\
\text { with following the trend }\end{array}$ \\
\hline Less working effort & $46-50$ hours & $0.175^{\star * *}(0.005)[253]$ \\
\hline
\end{tabular}

1) The table gives the coefficient of the Spearman rank correlation with the $p$-value in parentheses and the number of responses in suqared brackets.

Asterisks refer to level of significance: ${ }^{*} 10 \%,{ }^{* *} 5 \%,{ }^{* * *} 1 \%$. 


\section{TABLE 4. Herd behavior, sources of information and investment horizon}

"Please assess the following sources of information used in making investment decision." Six response categories, ranging from "highest relevance" (coded as 1) to "no relevance" (coded as 6).

"What is your personal forecasting horizon when making investment decisions?" Five response categories, ranging from "days" (coded as 1 ) to "years" (coded as 5).

\begin{tabular}{|c|c|c|c|}
\hline & $\begin{array}{l}\text { Share of high } \\
\text { importance }^{1)}\end{array}$ & $\begin{array}{l}\text { Rank correlation }{ }^{2)} \text { with } \\
\text { following the trend }\end{array}$ & $\begin{array}{l}\text { Ordered probit } \\
\text { regression }{ }^{3)}\end{array}$ \\
\hline \multicolumn{4}{|l|}{ Importance of information } \\
\hline Fundamentals & $95.1 \%$ & $-0.254^{* * *}(0.000)$ & $-0.244^{* * *}(0.001)$ \\
\hline Technical analysis & $70.7 \%$ & $0.426 * * *(0.000)$ & $0.260^{* * *}(0.000)$ \\
\hline Discussion with colleagues & $78.5 \%$ & $-0.116^{*} \quad(0.063)$ & $-0.058 \quad(0.263)$ \\
\hline Other market players & $31.2 \%$ & $0.148^{* *}(0.017)$ & $(0.691)$ \\
\hline Opinion leaders (Industry) & $19.0 \%$ & $0.194^{* * *}(0.002)$ & $0.137^{* *}(0.043)$ \\
\hline \multirow[t]{2}{*}{ Opinion leaders (Economy) } & $43.3 \%$ & $0.051 \quad(0.413)$ & $-0.027 \quad(0.631)$ \\
\hline & \multicolumn{2}{|c|}{$\begin{array}{l}\text { All managers' } \\
\text { mean answer }\end{array}$} & $\begin{array}{l}\text { Rank correlation }{ }^{2)} \text { with } \\
\text { following the trend }\end{array}$ \\
\hline Shorter investment horizon & \multicolumn{2}{|c|}{ 6-12 months } & $0.174^{* * *}(0.006)$ \\
\hline \multicolumn{4}{|c|}{$\begin{array}{l}\text { 1) The share of high importance is calculated as aggregated distribution to the answer categories } 1-3 \text {. } \\
\text { 2) The table gives the coefficient of the Spearman rank correlation with the p-value in parentheses. The } \\
\text { correlation is based on } 254 \text { to } 259 \text { valid responses. } \\
\text { The table gives beta coefficient estimates from an ordered probit regression of following the trend } \\
\text { with the p-value in parentheses. The dependent variable "I generally follow the trend" is classified in } \\
\text { six response categories, ranging from "completely agree" (coded as } 1 \text { ) to "completely disagree" (co- } \\
\text { ded as } 6 \text { ). } \\
\text { Asterisks refer to level of significance: * } 10 \%, * * 5 \%, * * * 1 \% \text {. }\end{array}$} \\
\hline
\end{tabular}

\section{TABLE 5. Herd behavior and risk taking behavior}

\begin{tabular}{l}
\hline "Please classify your personal risk-taking: In respect of professional investment decisions, I mostly \\
act..." six response categories ranging from 1 "very risk averse" up to 6 "little risk avers". \\
"Imagine someone offers you a bet and the odds are fifty-fifty. You will have to pay $€ 1,000$ from your \\
personal account if you lose. What would be the minimum amount you would expect to win to lure \\
you into accepting the bet?" \\
"In case of loss positions in my portfolio I generally wait for a price rebound instead of selling those \\
securities." Six response categories, ranging from 1 "completely agree" to 6 "completely disagree". \\
"I prefer to take profits instead of cutting losses when I am confronted with unexpected liquidity \\
demands." Six response categories, ranging from 1 "completely agree" to 6 "completely disagree".
\end{tabular}

\begin{tabular}{|c|c|c|}
\hline & $\begin{array}{c}\text { Share of } \\
\text { agreement }\end{array}$ & $\begin{array}{l}\text { Spearman rank correlation } \\
\text { with following the trend }\end{array}$ \\
\hline Higher risk aversion ${ }^{3)}$ & $\mathrm{n} / \mathrm{a}$ & $0.156^{* *} \quad(0.012) \quad[257]$ \\
\hline Higher minimum amount ${ }^{4)}$ & $\mathrm{n} / \mathrm{a}$ & $0.074 \quad(0.284) \quad[214]$ \\
\hline Higher loss aversion & $42.1 \%$ & $0.296^{* * *}(0.000)$ [258] \\
\hline Stronger disposition effect & $37.8 \%$ & $0.264^{* * *}(0.000)$ [258] \\
\hline
\end{tabular}

\footnotetext{
1) The share of agreement is calculated as aggregated distribution to the answer categories 1-3.

2) The table gives the coefficient of the Spearman rank correlation with the p-value in parentheses and the number of responses in suqared brackets.

3) All managers' mean answer is 3.5, indicating a "medium" extent of risk aversion.

4) All managers' median answer is $€ 1,750$.

Asterisks refer to level of significance: ${ }^{*} 10 \%,{ }^{* *} 5 \%,{ }^{* *} 1 \%$.
} 
TABLE 6. Multivariate analysis of triggers of herd behavior

\begin{tabular}{|c|c|c|c|}
\hline \multirow[t]{2}{*}{ Considered items } & \multicolumn{3}{|c|}{ Ordered probit regression of "I generally follow the trend' } \\
\hline & Beta coefficient & p-value & Standard error \\
\hline Herding benefits career & $0.156^{* *}$ & $(0.040)$ & 0.076 \\
\hline Working effort & -0.032 & $(0.614)$ & 0.065 \\
\hline \multicolumn{4}{|l|}{ Importance of information } \\
\hline Fundamentals & $-0.274^{* * *}$ & $(0.001)$ & 0.085 \\
\hline Technical analysis & $0.262^{* * *}$ & $(0.000)$ & 0.060 \\
\hline Discussion with colleagues & 0.009 & $(0.878)$ & 0.058 \\
\hline Other market players & -0.050 & $(0.482)$ & 0.072 \\
\hline Opinion leaders (industry) & 0.123 & $(0.101)$ & 0.075 \\
\hline Opinion leaders (economy) & $-0.116^{*}$ & $(0.070)$ & 0.064 \\
\hline Investment horizon & -0.037 & $(0.723)$ & 0.107 \\
\hline \multicolumn{4}{|l|}{ Risk taking behavior } \\
\hline Risk aversion (self-assessment) & $0.291^{* * *}$ & $(0.000)$ & 0.083 \\
\hline Requested minimum amount & $4.91 e^{-7}$ & $(0.352)$ & $5.28 e^{-7}$ \\
\hline Loss aversion & $0.210^{* * *}$ & $(0.002)$ & 0.069 \\
\hline Disposition effect & $0.098^{*}$ & $(0.094)$ & 0.058 \\
\hline
\end{tabular}

The dependent variable "I generally follow the trend" is classified in six response categories, ranging from "completely agree" (coded as 1) to "completely disagree" (coded as 6). Asterisks refer to level of significance: ${ }^{*} 10 \%,{ }^{* *} 5 \%,{ }^{* *} 1 \%$. Marginal effects of the ordered probit regression are presented in Annex 1.

\section{TABLE 7. Risk taking and herd behavior in the tournament}

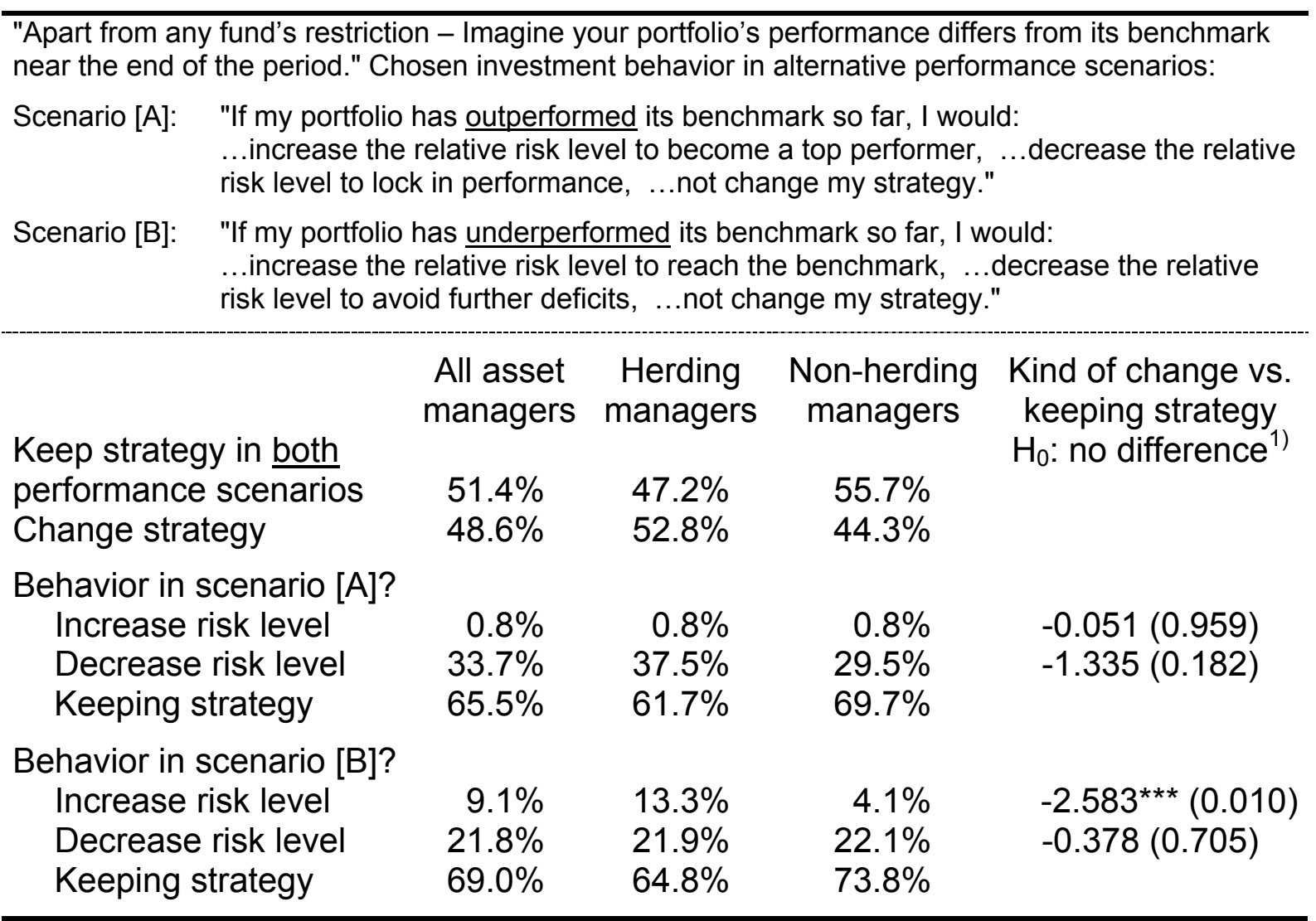

1) The table gives the z-value of the Mann-Whitney U-Test with the $p$-value in parentheses.

Asterisks refer to level of significance: ${ }^{*} 10 \%,{ }^{* *} 5 \%,{ }^{* * *} 1 \%$. 
ANNEX 1. Marginal Effects of multivariate analysis in Table 6

\begin{tabular}{|c|c|c|c|c|c|c|}
\hline \multirow[t]{2}{*}{ Considered items } & \multicolumn{6}{|c|}{$\begin{array}{l}\text { Marginal effects in ordered probit regression of "I I } \\
\text { generally follow the trend". Response categories: }\end{array}$} \\
\hline & \multicolumn{5}{|c|}{$\begin{array}{l}\text { Completely } \\
\text { agree }\end{array}$} & $\begin{array}{r}\text { Completely } \\
\text { disagree }\end{array}$ \\
\hline Herding benefits career & -0.062 & 0.031 & 0.027 & 0.003 & 0.000 & 0.000 \\
\hline $\begin{array}{l}\text { Working effort } \\
\text { Importance of information }\end{array}$ & 3 & 06 & 06 & & -0.000 & \\
\hline Fundamentals & 0.109 & -0.055 & -0.048 & -0.006 & -0.001 & -0.00 \\
\hline & & & & & 0.001 & \\
\hline & -0.004 & 0.002 & 0.002 & 0.000 & 0.000 & $8.11 \mathrm{e}^{-7}$ \\
\hline Oth & 0.020 & -0.010 & -0.009 & -0.001 & -0.000 & $-4.56 e^{-6}$ \\
\hline & & & & & & \\
\hline & & -0.023 & -0.020 & -0.003 & -0.000 & -0.00 \\
\hline Investment horizon & 0.146 & -0.007 & -0.006 & -0.001 & -0.000 & \\
\hline \multicolumn{7}{|l|}{ Risk taking behavior } \\
\hline Risk aversion (self-assessment) & -0.115 & 0.058 & 0.050 & 0.006 & 0.001 & 0.000 \\
\hline Requested minimum amount & $-1.96 e^{-7}$ & $79.80 e^{-8}$ & $8.52 e^{-8}$ & $1.07 e^{-8}$ & $1.49 e^{-9}$ & $94.44 \mathrm{e}^{-1}$ \\
\hline & & 0.042 & 0.036 & & 0.001 & \\
\hline Dispos & -0.039 & 0.020 & 0.017 & 0.002 & 0.000 & \\
\hline
\end{tabular}

